\title{
Transparency and information disclosure in China's environmental governance Lei Zhang ${ }^{1}$, Arthur PJ Mol${ }^{2}$ and Guizhen $\mathrm{He}^{3}$
}

\begin{abstract}
Given its past as a so-called information-poor and authoritarian country, China has recently made remarkable progress in information disclosure and environmental transparency. Since enacting the Open Government Information Regulations and the Environmental Information Disclosure Measures in 2008, China has advanced the actual amount of environmental information disclosed to civil society actors, the diversification and pluralism of environmental information suppliers and users, and the diversification in the methods of transparency and disclosure. This has significantly changed environmental governance in China. In practice, however, practical and more fundamental problems and limitations in environmental information disclosure continue to exist in China. Moreover, it is not yet clear what the actual effect of information disclosure is on environmental pollution reduction and environmental quality.
\end{abstract}

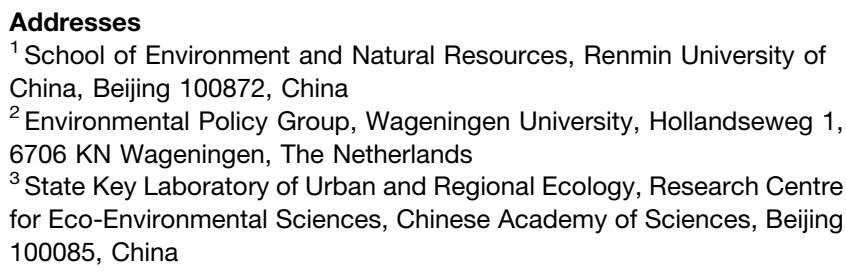

${ }^{1}$ School of Environment and Natural Resources, Renmin University of China, Beijing 100872, China

${ }^{2}$ Environmental Policy Group, Wageningen University, Hollandseweg 1, 6706 KN Wageningen, The Netherlands

${ }^{3}$ State Key Laboratory of Urban and Regional Ecology, Research Centre for Eco-Environmental Sciences, Chinese Academy of Sciences, Beijing 100085, China

Corresponding author: Mol, Arthur PJ (Arthur.Mol@wur.nl)

Current Opinion in Environmental Sustainability 2016, 18:17-24

This review comes from a themed issue on Sustainability governance and transformation 2016: Informational governance and environmental sustainability

Edited by Katrine Soma, Bertrum MacDonald, Paul Opdam and Catrien Termeer

For a complete overview see the Issue and the Editorial

Received 11 November 2014; Accepted 31 March 2015

Available online 10th April 2015

http://dx.doi.org/10.1016/j.cosust.2015.03.009

1877-3435/C 2015 Elsevier Ltd. All rights reserved.

\section{Introduction}

Environmental governance through information, for instance through the 1986 Emergency Planning and Right to Know Act of the United States, has been practiced as an complement to command-and-control and market-based modes of environmental governance [1-5]. The revolutionary developments in information and communication technology over the past two decades have accelerated this informational governance, spreading it around the globe to developing and transitional economies, including China. China has often been labeled a typical 'authoritarian' or 'paternalistic' state, where policies were made largely by the central government and implementation depended on the local governments. Lack of implementation incentives for local officials, deficient central supervision and absence of civil society participation and engagement have been blamed for poor enforcement of these policies.

China is of course not an average country when we consider environmental information disclosure and informational governance. For a long time, China has been considered an 'information-poor environment', where the state is in strong control of not only the economy but also information $[4,6,7]$. The main conventional information institutions, such as television, newspapers, the radio and news agencies have been kept in state hands for a long time, and information release through these institutions has been under strong state control. However, over the past two decades a significant change has taken place regarding the state's monopoly in information and informational processes [8]. And arguably the environmental field is leading in a cautious move to bounded information pluralism and transparency, caused by at least two processes. First, developments in information and communication technology have undermined the control of the state in information provisioning and dissemination. While the Chinese state undertakes major efforts to control the Internet [7,9], it faces the limits of total information control in the Information Age. Second, especially in the field of the environment the central government has allowed and even actively stimulated information disclosure and media openness, often with the idea to build countervailing power against local - state-owned or state-backed powerful polluters. This environmental transparency is often not supported by local authorities. With environmental information disclosure and more (media) freedom to report on environmental catastrophes and protests the central state hopes to counteract what it considers distortion of information by local and regional authorities. Hence, information disclosure becomes part of environmental governance.

In this article we review the policies, practices, limitations and effects of China's informational governance on the environment. We first assess the legal and policy 
developments, subsequently turn to the implementation practices and effects on polluters and local governments, and finally appraise the role of civil society and trust in information sources in informational governance.

\section{Legislation and policies}

Arguably, the 1989 Environmental Protection Law (EPL, Articles 11 and 31) was the first piece of legislation in China that provided a legal base for the production and public release of environmental quality and pollution reports, environmental accidents reports, environmental impacts assessment reports and information on illegal discharges of pollutants by industries. Environmental information disclosure, however, was considered a one-way dissemination tool (as intra-departmental or government-to-public information flow), rather than a governance instrument. Over the years, mandatory environmental information disclosure has been increasingly inserted in other national laws, such as those on noise prevention and control (Articles 19, 30,35 ), air pollution prevention and control (amended in 2000; Articles 20, 21, 23), water pollution prevention and control (amended in 2008; Articles 19, 56, 68), promotion of cleaner production (amended in 2012; Articles 10, 17, 27, 28, 36), and environmental impact assessment (Articles 5, $11,21)$. Often guidelines have been added to these laws to substantiate and operationalize disclosure requirements and policies, such as the recent disclosure guidelines for environmental impact assessments. In addition, sectoral and local experiments took place in applying environmental information disclosure as a governance instrument.

Environmental information disclosure really matured with the Environmental Information Disclosure Measures (EIDM), which came only into force in 2008 as the first sectoral operationalization of China's 2008 Open Government Information Regulations (OGIR). The main motivations behind the OGIR were to alleviate information asymmetry between actors; to gain political credit by improving transparency of governmental work; and to improve administrative performance $\left[10,11^{\bullet}, 12^{\bullet \bullet}\right]$. The 2008 EIDM forces governmental authorities at all levels as well as serious industrial polluters to disclose environmental information to the public. Provincial Environmental Protection Bureaus (EPBs) have to disclose environmental information to the public on four major categories: environmental laws and regulations; environmental quality; environmental management and supervision; and environmental accidents and emergency responses. EIDM also requires that so-called 'serious polluting enterprises' must disclose information on the concentration and volume of each pollutant discharged; the environmental facilities in operation; and the company's emergency response plan. The main goal of EIDM was to further involve new actors in environmental governance: the public, NGOs, and the media. EIDM was as much a codification of informational developments taking place in China since the turn of the millennium $[7,13]$, as a new venue to further push environmental disclosure practices and institutions towards informational governance.

Since EIDM environmental information disclosure policies have expanded. Most recently, disclosure of environmental information found a further and stronger legal basis in the 2014 Environmental Protection Law EPL, with an entire new chapter on information disclosure and participation of citizens in environmental governance $\left[14^{\bullet \bullet}, 15^{\circ}\right]$. Even the law-making itself (actually a revision of the $1989 \mathrm{EPL}$ ) was more open than ever, with unique disclosure of several drafts, ample opportunities for scientists and public to become involved and the employment of informational governance strategies by the Ministry of Environmental Protection (MEP), as we have discussed elsewhere $\left[14^{\bullet \bullet}, 16\right]$. With enforcing this EPL, MEP and EPBs can push further environmental information disclosure by detailing procedures, mechanisms and enforcement measures for effective public participation. The year of 2014 saw an intensive enactment of policy measures to guide information disclosure of different target groups: Regulation on the Implementation of the Law on Guarding State Secrets 2014, Interim Regulation on Enterprise Information Disclosure 2014, Measures on Selfmonitoring, Surveillance and Information Disclosure in National Key Monitored Enterprises 2014 (Trial), Measures on Pollution Sources Supervisory Monitoring and Surveillance and Information Disclosure in National Key Monitored Enterprises (Trial), and Guidelines on Construction Project EIA Governmental Information Disclosure 2014 (Trial). With all that China seems to have set a favorable legal and policy infrastructure for informational governance on the environment. China is no longer short of legal and policy instruments for furthering environmental transparency and information disclosure, although some scholars and stakeholders would prefer more instruments in these laws for enforcement of implementing these rules and regulation, and less exemption possibilities given to companies and local governments for actual environmental information disclosure $\left[12^{\bullet \bullet}\right]$.

\section{Implementation practices: authorities and polluters}

How have authorities and companies reacted to these environmental information disclosure laws and policies? Governmental evaluations of the implementation of EIDM 2008-2013 [17] document the progressive achievements in terms of an increased number of viewers of governmental websites with mandatory disclosed environmental information, growing environmental information requests received and answered (e.g. from 68 in 2008 to 1076 in 2013 by MEP), more information items being disclosed and a growing use of disclosure forms. Independent evaluations of EIDM $\left[10,11^{\bullet}, 18^{\circ}\right]$ unveiled problems and failures: a meager track record of slow, incomplete and sometimes unwilling implementation 
of EIDM by EPBs and polluting companies, often using Article 8 of OGIR (on exemption due to 'national security, public security, economic security or social stability') as arguments for continuing confidentiality of environmental information $\left[10,11^{\bullet}, 18^{\bullet}, 19\right]$. Sanctions on lack of implementation or on violations of EIDM have also not yet been reported. The MEP's initial refusal in 2013 to disclose the data from the first national soil pollution survey as state confidential (only finally released in 2014) further questioned the application of the confidentiality rule.

There are also cases in which governmental authorities have ignored information disclosure principles and rules. For instance, decisions on nuclear power plants construction were made with almost no information disclosure to the public living close to the newly build energy plants $[20,21]$. In addition, public participation and information disclosure during the environmental impact assessment (EIA) on construction and investment projects are required following the 2003 EIA Law, but the record of such participation and disclosure is rather poor [22,23]. Similar problems have been noticed regarding an innovative policy instrument called 'Environmental Impact Assessment Restriction Targeting Regions (EIARTR, Quyu Xianpi)'. The MEP introduced in 2007 the freezing of EIA approval of all new projects in an administrative region (e.g. a municipality or county), as a punishment for failing to meet regional environmental quality targets. This new administrative measure to safeguard regional environmental quality was also applied by provincial level EPBs [24]. But this freezing of EIA approval is controversial: questions have been raised by environmental law experts, the public and local governments regarding the legitimacy, transparency and environmental effectiveness of applying these measures.

Studies on mandatory or voluntary environmental and corporate social responsibility information disclosure by companies focus on either stock-listed companies $\left[25,26,27^{\bullet \bullet}\right]$, on local case studies $[19,28,29]$, on specific industrial sectors [25], on substances such as greenhouse gas reporting [30], on investors $\left[2,31^{\bullet \bullet}\right]$, or on industry samples according to size or pollution levels [32]. Together these studies show that information disclosure levels are related to organizational characteristics of industries (larger companies, foreign or state-owned companies and companies in polluting sectors disclose environmental information better) and to activities of other stakeholders (e.g. more pressure of governments, shareholders, creditors, and community groups result in more and better environmental information disclosure of companies). At the same time these studies show that overall the levels and details of company environmental disclosure in China are low. More than in OECD countries, companies disclose especially favorable and qualitative environmental information, and hardly problematic (accidents, emissions above standards) and quantitative data [30,32]. From all these studies there proves to be little solid, causal and convincing evidence on the relation between the degree and quality of environmental information disclosure and better environmental and/or economic performance [33].

Studies on company and city environmental performance rating and their disclosure started in 1999 with the socalled Green Watch programme. Initially, the former MEP together with the World Bank piloted an experiment on company environmental performance rating in two cities, which was extended to other provinces $\left[6,34,35,36^{\circ}\right]$. While positive associations were reported between environmental performance rating of disclosure programs and overall improvement of company environmental performance [33], also here scholars have cautioned for selection bias and influence of time [5,28]. Firms with better environmental ratings perceive positive impacts on market competitiveness, overall market value, and - to a lesser extent - relationships with different stakeholders [37]. Liu et al. [28] showed, however, that companies were not too impressed by these advantages of disclosed ratings, as poor ratings did not result in pressure from the various stakeholders and the public due to lack of consequences that affect companies' core interests. This might change for larger companies with the recent policies on Green Credit and Green Securities, where MEP has published a black list of companies that are no longer entitled to financial credit and listed companies on the Shanghai and Shenzhen stock markets have to disclose company environmental performance data for initial offerings or refinancing $\left[38^{\bullet}, 39^{\circ}\right]$.

Finally, informational governance and transparency has hardly taken off in value chains in China. In OECD countries environmental information on and transparency of products and production processes, especially in the form of third party logo's, labels, standards and product information, is increasingly governing the sustainability of value chains $\left[40^{\bullet \bullet}, 41\right]$. In China this kind of informational governance of value chains is only present in export chains (especially to European, North American and Japanese markets) or chains led by multinational companies (MNCs) [12 $\left.{ }^{\bullet \bullet}, 37\right]$, and hardly in value chains where production and consumption are largely limited to the domestic market [42] and developing countries. Even with respect to value chains that commonly raise citizenconsumer concerns, such as food products, informational governance in domestic value chains is largely absent $\left[43^{\circ}, 44\right]$. This is partly a result of limited consumer requests for environmental labels and the large distrust of Chinese consumers in national environmental labeling and information systems $[41,45,46]$.

Figure 1 illustrates the information disclosure process, showing that the actual functional pathways to achieve improved transparency and environmental effects depend 
Figure 1

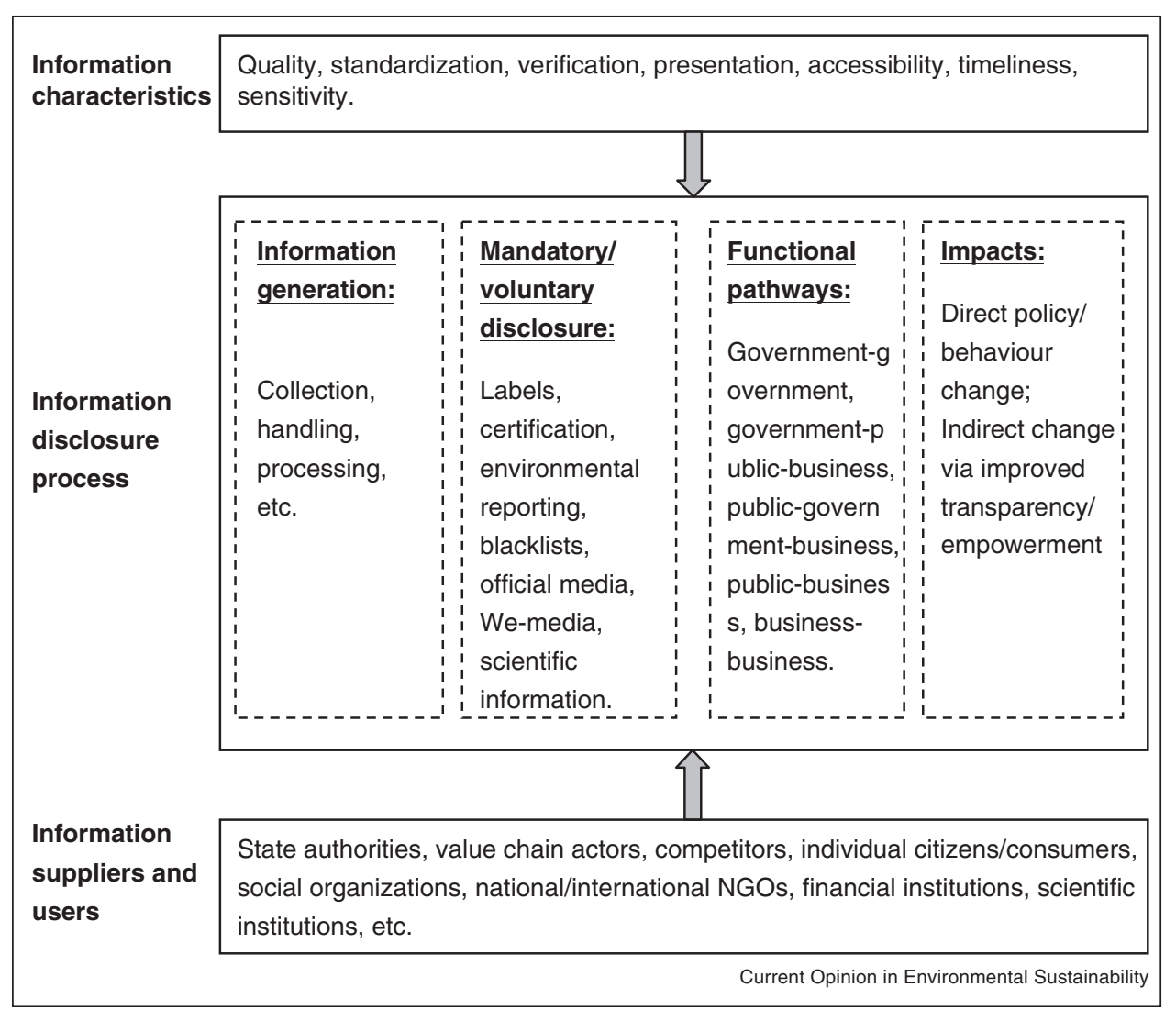

Dimensions of information disclosure.

on the information characteristics and which information suppliers and users are involved in the process, including societal actors that are discussed below.

\section{Civil society empowered with information}

The term 'civil society' has been used in many studies on China, often without proper differentiation, clarification or specification whether these studies targeted civil society organizations, social groups, NGOs, government-organized NGOs, the public in general, individuals, media or a mix of any of these categories. The common denominator seems often some kind of distance from the government and commercial sector, although even that is not always the case. Despite all the controversies and confusion around civil society in China, different statistics confirm the same trend: the boom in the number of registered domestic civil society organizations (including NGOs) is spectacular and environmental civil society organizations have formed a fast growing sector. The Ministry of Civil Affairs, for instance, reported that China went from zero domestic civil organizations before 1994 to 547549 civil organizations by 2013, of which some 7013 were listed in the category environmental and ecological protection [47]. This review applied a broad definition of civil society denoting the non-governmental and non-commercial reality in environmental information disclosure in China.

Partly enabled by a larger 'room for manoeuvre' [48 $]$ and partly through endogenous developments, China's civil society has been increasingly engaged in environmental information disclosure. Citizen complaints on pollution have been for quite some time a successful "citizen science' mechanism used by Chinese authorities to complement conventional governmental monitoring programs. These complaint systems also prioritize to some extent where governmental interventions for a better environment should be made, although most environmental complaints are made by more educated people and in wealthier areas and regions [7,49].

More recently, official complaint systems have been complemented by a variety of civil society engagements in information disclosure practices. Strong relations between the media and civil society [50,51], the emergence of investigative journalism [52] and decreasing central state control on media reporting of environmental misbehaviors has increased media reporting on environmental 
accidents, illegal pollution discharges and environmental protests over the past decade. Environmental accidents and pollution victims, local environmental protests, failing environmental authorities and new policy initiatives are increasingly disclosed in local and national media (newspapers, radio, television), not in the least by first being reported online [53]. This media coverage puts public pressure on those responsible to act in favor of the environment. Environmental information is being increasingly disclosed on planned para-xylene (PX) production facilities $\left[54^{\bullet}, 55\right]$, waste incinerator siting [56], groundwater pollution [57], food quality and safety $\left[43^{\circ}, 58\right]$, and environmental protests/activism [59,60]. But at the same time, in quite a number of cases this media disclosure does not come easily and/or is suppressed and prevented by local authorities and enterprises $\left[19,61^{\bullet}, 62\right]$. Several studies show that environmental media reporting can still be strongly framed and controlled by Beijing, such as in the case of nuclear power $[20,21,63,64]$.

The information and communication technology (ICT) revolution has further expanded the possibilities of civil society to obtain, produce, spread and disclose environmental information, increasing its role in informational governance in China $\left[9,61^{\circ}\right]$. Besides a large number of individual bloggers and Weibo (a Chinese micro blogging website, akin to a hybrid of Twitter and Face book) users, it is specially the Chinese non-governmental organization Institute of Public and Environment (IPE) that has together with Chinese and foreign partners - been leading the non-state disclosure of environmental information. IPE has constructed and continues to maintain and update online databases: on enterprise violations of air and water pollution legislation covering 300 cities and 31 provinces; the development of the Pollution Information Transparency Index (PITI) of initially 113 municipal government environmental disclosure practices (increased to 120 cities in their 2014 report) [18 ${ }^{\circ}$; the Air Quality Information Transparency Index of cities [65], and the Corporate Information Transparency Index [66]. These web-based systems release information over and assess the transparency of pollution sources throughout China, the air quality of a large number of major Chinese cities, and cover over 1600 companies. Moreover, some of these and other environmental databases have been used by innovative companies to build systems for realtime online environmental (especially air) quality information of Chinese (and foreign) cities (accessible through mobile phones), enhancing pressure on city governments (through media, complaining citizens and political representatives at higher levels) to clean up their living environment. Through different mechanisms of accountability, reputation and competition these disclosure systems have shown indeed some positive influence on environmental transparency as well as environmental performance [66]. In a number of cases companies and cities have sought to avoid being laggards in environmental pollution, environmental quality or the disclosure of environmental information, and improved their performance. But in numerous cities (including the capital Beijing) air quality indicators remain far above World Health Organization standards for too many days, and have hardly improved over the past years.

\section{Information and trust}

In all these practices of information disclosure, desired informational governance only works if information that can be obtained is trusted by the targeted groups. In China the trust profile amongst citizens in sources of environmental information provisioning is quite distinct from that found in western countries [13]. According to several surveys we conducted in recent years on information and trust using similar questions, the government, especially the central government, remains the most trusted information source in cases of nuclear power accidents, high speed train risk and rural industrial pollution (Table 1). This is partly due to a lack of alternative reliable sources, partly due to the adaptive capacity and competence the central (but not the local) government has shown during major emergency responses. But this strong position of the central government as trustful environmental information provider is less clear when it comes to sustainable and healthy food, where scientific experts seem to be a more trusted source of information $\left[43^{\bullet}, 45,46,67\right]$. Consistently, environmental information from local governmental authorities is much less trusted, as is shown in numerous case studies $\left[19,54^{\circ}\right]$.

Companies and non-governmental organizations are not widely seen as reliable sources of environmental information in various studies. Especially the position of nongovernmental organizations is fundamentally different from those in OECD countries, where they are often considered as major sources of reliable environmental information, next to scientists [41]. While in China civil society imposes pressure on industries or governmental

\begin{tabular}{|c|c|c|c|}
\hline \multicolumn{4}{|c|}{$\begin{array}{l}\text { Public trust in information sources on the environment in China } \\
\text { (in percentage of respondents) }\end{array}$} \\
\hline Sources & $\begin{array}{c}\begin{array}{c}\text { Nuclear } \\
\text { power } \\
n=226[21]\end{array} \\
\end{array}$ & $\begin{array}{c}\text { High speed } \\
\text { trains } \\
n=828[68]\end{array}$ & $\begin{array}{c}\text { Rural industrial } \\
\text { pollution } \\
n=523[19]\end{array}$ \\
\hline Government & $59 \%$ & $46 \%$ & $25 \%$ \\
\hline Companies & $10 \%$ & $6 \%$ & $5 \%$ \\
\hline Relatives/friends & $2 \%$ & $2 \%$ & $15 \%$ \\
\hline Scientists & $9 \%$ & $12 \%$ & $17 \%$ \\
\hline Media & $10 \%$ & $21 \%$ & $14 \%$ \\
\hline ENGOs & $1 \%$ & $3 \%$ & $11 \%$ \\
\hline $\begin{array}{l}\text { International } \\
\text { organizations }\end{array}$ & $5 \%$ & - & $13 \%$ \\
\hline Don’t know & $4 \%$ & $10 \%$ & - \\
\hline Total & $100 \%$ & $100 \%$ & $100 \%$ \\
\hline
\end{tabular}


agencies, it rarely has the legitimacy, authority and capacity of the central government according to ordinary citizens confronted with environmental risks. This profile of citizen trust in environmental information is dependent on levels of income and education, as higher levels of education and income reduce the dominance of the central government as trustful environmental information source.

This trust in NGO environmental information seems to be different with respect to institutional decision makers, as companies and city governments have considerable trust in data disclosed by the Chinese NGO IPE.

\section{Future outlook}

Neither the concept of 'authoritarianism' nor 'paternalism' can really capture the dynamics and complexities of the political reality with respect to environmental information disclosure in contemporary China. The coexistence of encouragement and constraint, confrontation and cooperation, surveillance and transparency features the coevolving state-society relationship in China's environmental governance. With states often brought together under the label of authoritarian regimes, such as Russia, Vietnam, and Singapore, China shares the strong position of the central state, also in the production, dissemination, access and control of information. But more than in Russia and Vietnam, in China the state has become responsive to environmental information demands of society lately. It has learned to cooperate with non-governmental organizations and institutions to improve the enforcement of central environmental policies at local level (using public pressure, for instance) and ultimately improve its legitimacy as an environmental state. In that sense, China is practicing informational governance of the environment, by applying transparency and information disclosure to govern environmental protection. Although perhaps unexpected in a country with an 'information-poor' environment, China has definitely jumped on the bandwagon of informational governance on the environment by making significant progress in environmental information disclosure over the past decades.

While in OECD countries environmental transparency has come under critical scrutiny [69] because of, among others, information overflow [70], this is not (yet) the case in China. While there is definitely strategic use of environmental information disclosure by the Chinese government, and (unintended) perverse effects can follow from environmental information disclosure (e.g. when powerful private companies enter the environmental information battlefield), all scholars see the furthering of transparency and disclosure of environmental information as much wanted and needed developments in China. It might not always directly lead to environmental improvements (as indicated above), but its indirect effects in terms of environmental awareness and learning, as well as empowering citizens, are additional valuable effects. Crucial in China is that too many companies and governmental authorities are still unwilling or actively hindering information disclosure for wider constituencies and there is still a major information disparity. In addition, the overall quality of environmental information disclosed by governmental agencies or companies remains low in terms of adequacy, reliability, credibility, timelines, and usefulness [10,22,71]. More verifiable information, widely disclosed and active public debate and learning following that information will advance directly and indirectly — informational governance.

These are also the future challenges for informational governance in China: improvement of environmental information accessibility and information quality. This is not primarily a technical issue of better digital information systems, or better and more widespread monitoring programs. The challenges are first and foremost related to breaking down the political, social and institutional barriers that hinder environmental information disclosure, and further the debate on quality and verification of environmental information. Also after coping with these challenges one key question remains: does environmental information disclosure improve environmental performance of governmental agencies and firms? While most transparency studies (in China and elsewhere $\left.\left[27^{\bullet \bullet}, 33,64,67\right]\right)$ show ambivalent environmental improvements resulting from information disclosure, Tan [13] interestingly investigated multiple pathways (see Figure 1) on how environmental improvements can be achieved through information disclosure. Such an approach may lead to more 'targeted transparency' [52]: disclosure directed at concrete mechanisms and target groups that can achieve environmental improvements.

\section{Acknowledgements}

Funding support is acknowledged from the Ministry of Education of China (NCET10-0806), the National Natural Science Foundation of China

(71103175), and Netherlands Royal Academy of Arts and Sciences (KNAW).

\section{References and recommended reading}

Papers of particular interest, published within the period of review, have been highlighted as:

- of special interest

$\bullet$ of outstanding interest

1. Esty D: Environmental protection in the information age. New York Univ Law Rev 2004, 79:115-211.

2. Dasgupta S, Wang H, Wheeler D: Disclosure strategies for pollution control. In The International Yearbook of Environmental and Resource Economics 2006/2007: A Survey of Current Issues. E3ittleldby Tietenberg T, Folmer H. Edward Elgar Publishers; 2006 :

3. Mol APJ: Environmental governance in the information age: the emergence of informational governance. Environ Plan $\mathrm{C}$ 2006, 24:497-514.

4. Mol APJ (Ed): Environmental Reform in the Information Age. Cambridge University Press; 2008. 
5. Jin Y, Wang H, Wheeler D: Environmental Performance Rating and Disclosure: An Empirical Investigation of China's Green Watch Program. World Bank; 2010.

6. Wang H, Greer L, Lin X: Practice and inspiration of environmental information disclosure. World Environ 2008, 5:24-26.

7. Mol APJ: Environmental governance through information: China and Vietnam. Singapore J Trop Geo 2009, 30:114-129.

8. Scotton JF, Hachten WH (Eds): New Media for a New China. Wiley-Blackwell; 2010.

9. Yang G: Internet activism \& the party-state in China. Daedalus 2014, 143:110-123.

10. Zhang L, Mol APJ, He GZ, Lu YL: An implementation assessment of China's environmental information disclosure decree. J Environ Sci 2010, 22:1649-1656.

11. Mol APJ, He GZ, Zhang L: Information disclosure in

- environmental risk management: developments in China. J Curr Chin Affairs 2011, 40:163-192.

This article provides a valuable assessment of information disclosure policies by governmental authorities and companies through the implementation of the Environmental Information Disclosure Measures.

12. Tan Y: Transparency without democracy: the unexpected - $\quad$ effects of China's environmental disclosure policy. Gov Int J Policy Admin Inst 2014, 27:37-62.

The most recent study on environmental disclosure and transparency using environmental authoritarianism framework, illustrated different pathways towards transparency in two cases. The 'unexpected effects' discovered by the author actually showed the limited explaining power of environmental authoritarianism in case of China.

13. He GZ, Mol APJ, Lu YL: Trust and credibility in governing China's risk society. Environ Sci Technol 2012, 46:7442-7443.

14. Zhang L, He GZ, Mol APJ, Zhu X: Power politics in the revision of

•• China's Environmental Protection Law. Environ Polit 2013, 22:1029-1035.

This article gives a clear account of the revising process and politics of China's Environmental protection Law, including the debates and legislation on environmental information disclosure. The law revision process itself is a good example for information disclosure and transparency.

15. Zhang L, He GZ, Mol APJ: China's new Environmental

- $\quad$ Protection Law: a game changer? Environ Dev 2015, 13:1-3. A concise assessment of the improvements in China's new Environmental Protection Law, with a comparison per article of similarities and differences with the initial EPL.

16. He GZ, Zhang L, Mol APJ, Lu YL, Liu JG: Revising China's environmental law. Science 2013, 341:133.

17. MEP: Provincial EPB websites evaluation 2007-2012. Information Centre of the Ministry of Environmental Protection; 2008-2013.

18. IPE, NTDC: The First, Second, Third, and Fourth Assessment of

- Pollution Information Transparency Index (PITI). Institute of Public \& Environmental Affairs and Natural Resources Defense Council; 2009-2014.

These reports contain a systematic assessment of pollution information transparency of Chinese cities and corporations.

19. He GZ, Zhang L, Mol APJ, Wang TY, Lu YL: Why the small and medium-sized chemical companies continue to pose severe environmental risks in rural China. Environ Pollut 2014 185:158-167.

20. He GZ, Mol APJ, Zhang L, Lu YL: Nuclear power in China after Fukushima: understanding public knowledge, attitudes and trust. J Risk Res 2014, 17:435-451.

21. He GZ, Mol APJ, Zhang L, Lu YL: Public participation and trust in nuclear power development in China. Renew Sust Energy Rev 2013, 23:1-11.

22. He GZ, Lu YL, Mol APJ, Beckers T: Changes and challenges of China's environmental management. Environ Dev 2012 3:25-38.

23. Wang Y, Morgan RK, Cashmore M: Environmental impact assessment of projects in the People's Republic of China: new law, old problems. Environ Impact Ass Rev 2003, 23:543-579.
24. Zhu X, Zhang L, Ran R, Mol APJ: Regional restrictions on EIA approval in China: the legitimacy of environmental authoritarianism. J Clean Prod 2015, 92:100-108.

25. Zeng SX, Xu XD, Dong ZY, Tam Vivian WY: Towards corporate environmental information disclosure: an empirical study in China. J Clean Prod 2010, 18:1142-1148.

26. Noronha C, Tou S, Cynthia MI, Guan JJ: Corporate social responsibility reporting in China: an overview and comparison with major trends. Corp Social Respon Environ Manage 2013, 20:29-42.

27. Meng XH, Zeng SX, Shi JJ, Qi GY, Zhang ZB: The relationship

- between corporate environmental performance and environmental disclosure: An empirical study in China. J Environ Manage 2014, 145:357-367.

This article assesses how corporate environmental performance is affected their environmental information disclosure. It provides additional evidence for a nonlinear relationship between environmental performance and disclosure.

28. Liu XB, Anbumozhi V: Determinant factors of corporate environmental information disclosure: an empirical study of Chinese listed companies. J Clean Prod 2009, 17:593-600.

29. Xu XD, Zeng SX, Tam CM: Stock market's reaction to disclosure of environmental violations: evidence from China. J Bus Ethics 2012, 107:227-237.

30. Chu CL, Chatterjee B, Brown A: The current status of greenhouse gas reporting by Chinese companies: a test of legitimacy theory. Manage Audit J 2012, 28:114-139.

31. Lu Y, Indra A: Stakeholders' power, corporate characteristics,

- $\quad$ and social and environmental disclosure: evidence from China. J Clean Prod 2014, 64:426-436.

This article establishes a social and environmental information disclosure index including both quantitative and qualitative indicators, and analyzes the role of various stakeholders in influencing corperate disclosure behaviors.

32. Kuo L, Yeh CC, Yu HC: Disclosure of corporate socia responsibility and environmental management: evidence from China. Corp Social Respon Environ Manage 2012, 19:273-287.

33. Yu Z, Jian J, He P: The study on the correlation between environmental information disclosure and economic performance. Energy Procedia 2011, 5:1218-1224.

34. Wang $\mathrm{H}, \mathrm{Bi} \mathrm{J}$, Wheeler D: Environmental Performance Rating and Disclosure: China's Green-Watch Program. World Bank; 2002.

35. Liu B, Yu Q, Zhang B, Bi J, Ge J, Yuan Z, Yu Y: Does the Green Watch program work?. Evidence from a developed area in China. J Clean Prod 2010, 18:454-461.

36. Liu B, Yu Q, Bi J, Zhang B, Ge J, Bu M: A study on the short-term and long-term corporate responses to the Green Watch Program: evidence from Jiangsu, China. J Clean Prod 2012, 24:132-140

This article provides a valuable assessment of the environmental effects of the Green Watch Program in Jiangsu province.

37. Liu X, Yu Q, Fujitsuka T, Liu B, Bi J, Shishime T: Functional mechanisms of mandatory corporate environmental disclosure: an empirical study in China. J Clean Prod 2010 18:823-832.

38. Li W, Hu M: An overview of the environmental finance policies

- $\quad$ in China: retrofitting an integrated mechanism for environmental management. Front Environ Sci Eng 2014 8:316-328

A useful overview of the recently developed Green Credit and Green securities policies in China.

39. Wang $\mathrm{H}$, Bernell D: Environmental disclosure in China: an

- examination of the green securities policy. J Environ Dev 2013, 22:339-369.

This article examines environmental disclosure in Green Securities policy in China.

40. Bush SR, Oosterveer P, Bailey M, Mol APJ: Sustainability

- governance of chains and networks: a review and future outlook. J Clean Prod 2015 http://dx.doi.org/10.1016/ j.jclepro.2014.10.019. 
A most useful review article of studies on sustainable value chains and networks, including informational governance perspectives.

41. Mol APJ: Transparency and value chain sustainability. J Clean Prod 2015 http://dx.doi.org/10.1016/j.jclepro.2013.11.012.

42. Zhu Q, Geng Y: Drivers and barriers of extended supply chain practices for energy saving and emission reduction among Chinese manufacturers. J Clean Prod 2013, 40:6-12.

43. Mol APJ: The role of transparency in governing China's food - $\quad$ quality: a review. Food Control 2014, 43:49-56.

Assesses the role of transparency and information disclosure in China's food policy and food value chains, and their contribution to more sustainable food provision and consumption.

44. Zhang L, Xu Y, Oosterveer P, Mol APJ: Consumer trust in different food provisioning schemes: evidence from Beijing, China. J Clean Prod 2015. in press.

45. Cheng $\mathrm{H}$ : Cheap capitalism. A sociological study of food crime in China. Brit J Criminol 2012, 52:254-273.

46. Liu R, Pieniak Z, Verbeke W: Consumers' attitudes and behaviour towards safe food in China: a review. Food Control 2013, 33:93-104

47. Ministry of Civil Affairs of People's Republic of China: Social Services Development Statistics Bulletin 2013. Ministry of Civil Affairs2014. http://www.mca.gov.cn/article/zwgk/mzyw/201406/ 20140600654488.shtml.

48. Zhan X, Tang SY: Political opportunities resource constraints - $\quad$ and policy advocacy of environmental NGOs in China. Public Adm 2013, 91:381-399.

This article examines the political and institutional factors that have constrained or facilitated NGO policy advocacy activities. It helps to understand the role of environmental NGOs in informational environmental governance in China.

49. Dong Y, Ishikawa M, Liu X, Hamori S: The determinants of citizen complaints on environmental pollution: an empirical study from China. J Clean Prod 2011, 19:1306-1314.

50. Xie L: China's environmental activism in the age of globalization. Asian Polit Policy 2011, 3:207-224

51. Gang C: Politics of China's Environmental Protection. Problems and Progress. Singapore: World Scientific Publishing; 2009.

52. De Burgh H, Rong Z: China's Environment \& China's Environment Journalists. A Study. Bristol: Intellect; 2011.

53. Tang L, Sampson $\mathrm{H}$ : The interaction between mass media and the internet in non-democratic states: the case of China. Media Cult Soc 2012, 34:457-471.

54. Li WX, Liu JY, Li DD: Getting their voices heard: three cases

- of public participation in environmental protection in China. $J$ Environ Manage 2012, 98:65-72.

This article illustrates possible pathways for public participation in environmental protection in three cases.

55. Hung CF: Citizen journalism and cyberactivism in China's antiPX plant in Xiamen, 2007-2009. China Int J 2013, 11:40-54.
56. Johnson $\mathrm{T}$ : The health factor in anti-waste incinerator campaigns in Beijing and Guangzhou. China Quart 2013, 214:356-375.

57. Ma J, Webber M, Finlayson BL: On sealing a lakebed: mass media and environmental democratisation in China. Environ Sci Policy 2009, 12:71-83.

58. Holtkamp P, Liu WM: Regional patterns of food safety in China: what can we learn from media data? China Econ Rev 2014, 30:459-468.

59. Deng Y, Yang G: Pollution and protest in China: environmental mobilization in context. China Quart 2013, 214:321-336.

60. Van Rooij B: The people vs. pollution: understanding citizen action against pollution in China. J Contemp China 2010, 19:55-77.

61. Tilt B, Xiao Q: Media coverage of environmental pollution in the

- People's Republic of China: responsibility, cover-up and state control. Media Cult Soc 2010, 32:225-245.

This article discussed the roles of media in environmental governance in China.

62. Stern RE: Environmental Litigation in China. A study in Political Ambivalence. Cambridge: CUP; 2013.

63. Wang Y, Li N, Li J: Media coverage and government policy of nuclear power in the People's Republic of China. Prog Nucl Energy 2014, 77:214-223.

64. Wang Q, Chen X: Regulatory transparency. How China can learn from Japan's nuclear regulatory failures? Renew Sustain Energy Rev 2012, 16:3574-3578.

65. Hsu A, Sherbinin A, de Shi H: Seeking truth from facts: the challenge of environmental indicator development in China. Environ Dev 2012, 3:39-51.

66. IPE, NRDC: Corporate Information Transparency Index. Institute of Public \& Environmental Affairs and Natural Resources Defense Council; 2014:. http://www.ipe.org.cn/about/notice_de. aspx?id=11644.

67. Liu R, Pieniak Z, Verbeke W: Food-related hazards in China: consumers' perceptions of risk and trust in information sources. Food Control 2014, 46:291-298.

68. He GZ, Mol APJ, Lu YL: Environmental risks of high-speed railway in China: public participation, perception and trust. Environ Dev 2015 http://dx.doi.org/10.1016/j.envdev.2015. 02.002

69. Gupta A, Mason M (Eds): Transparency in Global Environmental Governance: A Critical Perspective. Cambridge, MA: MIT; 2014.

70. Mol APJ: The future of transparency: power, pitfalls and promises. Global Environ Polit 2010, 10:132-143.

71. Ma B, Song G, Zhang L, Sonnenfeld DA: Explaining sectoral discrepancies between national and provincial statistics in China. China Econ Rev 2014, 30:353-369. 